\section{Pollen Viability and Vigor in Hybrid Southern Highbush Blueberries (Vaccinium corymbosum L. Xspp.)}

\author{
Gregory A. Lang and E. James Parrie \\ Department of Horticulture, Louisiana Agricultural Experiment Station, \\ Louisiana State University Agricultural Center, Baton Rouge, LA 70803
}

Additional index words. multiple pollen tubes, tetrad germination, pollen grain germination, nutrient agar, Vaccinium darrowi, V. ashei, V. angustifolium

\begin{abstract}
Pollen from six southern highbush blueberry cultivars derived from Vaccinium corymbosum $\mathrm{L}$. and one or more other species (V. darrowi Camp, V. ashei Reade, and $V$. angustifolium Aiton) was incubated on nutrient agar to determine tetrad viability, pollen tube growth rates, and incidence of multiple pollen tube germinations. 'Avonblue' pollen had a significantly lower tetrad germination percentage than 'Georgiagem', 'Flordablue', 'Sharpblue', 'Gulfcoast', or 'O'Neal', all of which had $>90 \%$ viable tetrads. The in vitro growth rate of ' $O$ 'Neal' pollen tubes was significantly higher than the growth rates of 'Sharpblue' and 'Georgiagem pollen tubes. Of those tetrads that were viable, more than two pollen tubes germinated from $83 \%$ and $91 \%$ of the 'Gulfcoast' and 'Sharpblue' tetrads, respectively, while only $11 \%$ of the 'Flordablue' tetrads produced more than two pollen tubes. The total number of pollen tubes germinated per 100 tetrads ranged from 157 ('Flordablue') to 324 ('Sharpblue'), resulting in actual pollen grain viabilities ranging from $39 \%$ to $81 \%$. Genetic differences in pollen vigor, as indicated by pollen viability, pollen tube growth rates, and multiple pollen tube germinations, may influence blueberry growers' success in optimizing the beneficial effects of cross-pollination on fruit development.
\end{abstract}

Early ripening southern highbush blueberries, which are complex hybrids involving Vaccinium corymbosum, V. darrowi, V. ashei, and/or $V$. angustifolium, supply an early market at premium prices for blueberry growers from the Gulf coastal plains (Lang and Danka, 1992; Lyrene and Sherman, 1984). Improved knowledge of southern highbush fruit development and ripening is vital to full realization of their genetic potential. Since their interspecific ancestry includes diploid, tetraploid, and hexaploid species ranging from self-fruitful to self-incompatible, one of the first factors to study with regard to fruit development is pollen viability and vigor.

Ranges in pollen viability have been reported from $48 \%$ to $99 \%$ and from $14 \%$ to 98\% for rabbiteye and lowbush blueberry selections, respectively (Cockerham and Galletta, 1976). Differences in pollen viability may contribute to the differences in fruit set and development observed among highbush blueberry cultivars (Eck, 1986). Brewer and Dobson (1969) reported that 'Rubel' pollen germinated in vitro and in vivo at significantly higher levels than 'Jersey' (45\% vs.

\footnotetext{
Received for publication 1 July 1991. Accepted for publication 12 Nov. 1991. Approved for publication by the Director of the Louisiana Agricultural Experiment Station as manuscript no. 91-285324. We thank N.S. Lang, P.M. Lyrene, E.N. O'Rourke, and E.E. Puls for their critical reviews of the manuscript. The cost of publishing this paper was defrayed in part by the payment of page charges. Under postal regulations, this paper therefore must be hereby marked advertisement solely to indicate this fact.

${ }^{1}$ To whom reprint requests should be addressed.
}

contradicted Eck's interpretation. To our knowledge, quantitative data on the ability of southern highbush cultivars to germinate multiple pollen tubes have not been published.

The effects of interspecific hybridization on pollen viability and vigor of southern highbush cultivars are still unclear; reports are limited and seemingly contradictory. In vitro pollen viability percentages range from $22 \%$ for 'Avonblue' and $48 \%$ for 'Sharpblue' (Goldy and Lyrene, 1983) to 90\% (using acetocarmine staining) for 'Avonblue' (Gupton, 1984). The former authors suggested that the complex, diverse heritage of these interspecific hybrids may result in reduced fertility, as manifested by poor pollen germination.

Since little is known about the pollen-pistil biology of southern highbush blueberries, the objectives of this experiment were to characterize a) pollen viability (as measured by tetrad germination), b) pollen vigor (as measured by pollen tube growth rate), and c) incidence of multiple pollen tubes (allowing estimation of pollen grain viability) for 'Sharpblue', 'Flordablue', 'Avonblue', 'Gulfcoast', 'Georgiagem', and 'O'Neal' southern highbush blueberries.

Plant/pollen materials. Four-year-old potted 'Avonblue', 'Flordablue', and 'Sharpblue' plants and 3-year-old potted 'Georgiagem', 'Gulfcoast', and 'O'Neal' plants were moved in February from a shadehouse into refrigerated storage (7C). After 4 weeks, flowers were forced at $25 \mathrm{C}$ in the laboratory. Flowers were tagged at anthesis, and pollen was collected randomly from flowers of the same physiological age (24 h after opening of the corolla) at various shoot locations within and among 50 plants of each cultivar. Pollen from all plants of each cultivar was pooled for use as a treatment.

Pollen tetrad viability. For this in vitro experiment, "pollen tetrad viability" refers only to the ability of a tetrad to germinate, rather than the ability to also effect fertilization. Since some previous studies of pollen viability are actually based on tetrad, rather than individual grain, germination (Brewer and Dobson, 1969), viability is expressed as the percentage of pollen tetrads with one or more grains producing a pollen tube at least as long $(\approx 30 \mu \mathrm{m})$ as the tetrad diameter (Cockerham and Galletta, 1976). Pollen grain

Table 1. Pollen tetrad viability (germination percentages) and mean in vitro pollen tube growth rates of six southern highbush blueberry cultivars.

\begin{tabular}{lcc}
\hline Cultivar & $\begin{array}{c}\text { Tetrad } \\
\text { germination }(\%)\end{array}$ & $\begin{array}{c}\text { Mean pollen tube } \\
\text { growth rate } \\
\left(\mu \mathrm{m} \cdot \mathrm{h}^{-1}\right)\end{array}$ \\
\hline Avonblue & $79.5 \mathrm{~b}^{\mathbf{2}}$ & $30 \mathrm{ab}$ \\
Flordablue & $94.8 \mathrm{a}$ & $30 \mathrm{ab}$ \\
Georgiagem & $96.3 \mathrm{a}$ & $28 \mathrm{~b}$ \\
Gulfcoast & $93.8 \mathrm{a}$ & $38 \mathrm{ab}$ \\
O'Neal & $90.5 \mathrm{a}$ & $40 \mathrm{a}$ \\
Sharpblue & $94.3 \mathrm{a}$ & $26 \mathrm{~b}$
\end{tabular}

"Mean separation in columns by Duncan's multiple range test, $P=0.05$. 
Table 2. Percentage of multiple pollen tube germinations from viable pollen tetrads and pollen grain viability (germination percentages) of six southern highbush blueberry cultivars.

\begin{tabular}{lccccc}
\hline \hline & \multicolumn{4}{c}{$\begin{array}{c}\text { Viable tetrads with } \\
\text { two or more pollen tubes (\%) }\end{array}$} & \\
\cline { 2 - 4 } Cultivar & \multicolumn{3}{c}{ No. pollen tubes } & Pollen grain \\
\cline { 2 - 4 } & 2 & 3 & 4 & Total & germination (\%) \\
\hline Avonblue & 50 & 25 & 2 & $77 \mathrm{c}^{\mathbf{z}}$ & 40.9 \\
Flordablue & 43 & 10 & 1 & $54 \mathrm{~d}$ & 39.3 \\
Georgiagem & 35 & 29 & 29 & $93 \mathrm{~b}$ & 67.4 \\
Gulfcoast & 17 & 53 & 30 & $100 \mathrm{a}$ & 73.4 \\
O'Neal & 29 & 32 & 24 & $85 \mathrm{~b}$ & 60.0 \\
Sharpblue & 9 & 38 & 53 & $100 \mathrm{a}$ & 81.1 \\
\hline
\end{tabular}

${ }^{2}$ Mean separation by Duncan's multiple range test, $P=0.05$.

'Pollen grain germination percentage $=[$ (total number of pollen tubes $/ 100$ germinating tetrads) $\times$ (tetrad germination percentage)]/(four grains/tetrad).

viability was calculated as described below, taking into account multiple pollen tube germination from each tetrad.

In vitro tetrad viability tests were conducted using petri dishes containing $30 \mathrm{ml}$ of a nutrient agar medium [10\% sucrose, 100 ppm $\mathrm{H}_{3} \mathrm{BO}_{3}, 300 \mathrm{ppm} \mathrm{Ca}\left(\mathrm{NO}_{3}\right)_{2} \cdot \mathrm{H}_{2} \mathrm{O}, 200$ $\mathrm{ppm} \mathrm{MgSO}_{4} \cdot 7 \mathrm{H}_{2} \mathrm{O}, 100 \mathrm{ppm} \mathrm{KNO}$, and $2.5 \%$ water agar] (Stushnoff and Feliciano, 1968). Each petri dish was dusted evenly with fresh pollen, then covered and incubated at 25C. After $24 \mathrm{~h}, 300$ random pollen tetrads per dish were examined using a light microscope $(\times 100)$. There were four replications for each cultivar.

Pollen tube growth rate. Nutrient agar plates were dusted with fresh pollen and incubated at $24 \mathrm{C}$ for $72 \mathrm{~h}$. Beginning $4 \mathrm{~h}$ after incubation began, plates were removed every $2 \mathrm{~h}$, and pollen tube lengths were determined under a light microscope $(\times 100)$. Measurements, which began at different observation periods based on when each pollen tetrad germinated, were made with a calibrated micrometer disk (Bausch and Lomb no. 31-1605; Rochester, N.Y.) placed on the eyepiece diaphragm of the microscope. Individual pollen tube measurements ceased whenever a pollen tube burst (generally $\approx 60 \mathrm{~h}$ after incubation began), as often occurs for in vitro agar tests (Galletta, 1983). There were four replications of 100 pollen tubes per dish for each cultivar.

Multiple pollen tubes and pollen grain viability. Nutrient agar plates were prepared and dusted as described above, then incubated at $24 \mathrm{C}$. After $24 \mathrm{~h}, 100$ pollen tetrads per dish were examined under a light microscope $(\times 100)$. Only pollen tubes longer than $\approx 30 \mu \mathrm{m}$ were counted. There were four replications for each cultivar. Actual pollen grain germination percentage, as indicated by total pollen tube production, was calculated for each cultivar by $[$ (mean number of pollen tubes in 100 germinating tetrads $) \times($ percent pollen tetrad germination)]/(four grains/tetrad).

All data were analyzed by analysis of variance, and mean separations were calculated by Duncan's multiple range test.

Southern highbush pollen tetrad viability. In a preliminary experiment to compare a simple water agar (Brewer and Dobson, 1969), the nutrient agar described, and a crystal-violet staining technique for assess- ing in vitro pollen viability (Stushnoff and Feliciano, 1968), the nutrient agar yielded the most consistent and accurate results (Parrie, 1990). Southern highbush pollen tetrad germination was poor $(\approx 50 \%)$ on water agar alone, and crystal-violet staining yielded variable results. The variability associated with staining is often due to false positive pollen viabilities (Parfitt and Ganeshan, 1989; Werner and Chang, 1981). However, using nutrient agar, in vitro tetrad viability was high and similar among all cultivars except 'Avonblue', for which it was significantly lower ( $\approx 80 \%$ vs. $90 \%$ to $96 \%$ for the others) (Table 1).

Pollen tubegrowth. Although in vitro pollen tube growth rates may not be representative of in vivo growth rates due to confounding influences associated with the stylar tissue, in vitro data can provide an indication of inherent pollen vigor. The six southern highbush cultivars in this study had significantly different in vitro mean pollen tube growth rates, ranging from 26 to $40 \mu \mathrm{m} \cdot \mathrm{h}$ (Table 1). Based on these data, pollen of 'O'Neal' was more vigorous than that of 'Sharpblue' or 'Georgiagem'. Blueberry pollen tubes will reach the base of the style within 48 to $72 \mathrm{~h}$ of pollination (El-Agamy et al., 1982; Galletta, 1983); clearly, at the in vitro rates reported here, pollen tubes would take at least twice as long to traverse a similar distance. Anatomical studies of pollinated blueberry styles are needed to verify the in vivo significance of these in vitro rate data.

Multiple pollen tubes and pollen grain viability. In contrast to Eck's (1986) conclusion that multiple pollen tubes are infrequent in blueberries, all of the southern highbush cultivars in this study exhibited a substantial level of multiple pollen tube germination (Table 2). All 'Sharpblue' and 'Gulfcoast' tetrads that germinated had multiple tubes, and more than $75 \%$ of the germinated tetrads from 'Avonblue', 'Georgiagem', and 'O'Neal' had multiple pollen tubes. Only 'Flordablue' tetrads germinated about as many single as multiple pollen tubes. The propensity for two, three, or four pollen tubes per germinating tetrad also varied among cultivars, yet distribution of this tendency was not necessarily in accordance with pollen grain viability (Table 2). More than half of 'Sharpblue' germinated tetrads had four pollen tubes, while more than half of 'Gulfcoast' germinated tetrads had three pollen tubes. Germination of four pollen tubes from 'Avonblue' or 'Flordablue' tetrads was extremely rare. Consequently, assumptions regarding the independence of each grain in a tetrad, and thus whether multiple pollen tube germination may be a measure only of viability or of vigor as well, remains to be tested.

The interaction between pollen tetrad viability and the propensity for multiple pollen tube germination was calculated as actual pollen grain germination percentage, a measure of each cultivar's ability to generate potentially fertile sperm (Table 2). Based on its high propensity to generate four pollen tubes and high tetrad viability, 'Sharpblue' had the highest pollen grain viability, followed by 'Gulfcoast' and 'Georgiagem'. Much lower values (less than half that of 'Sharpblue') were recorded for 'Flordablue' (due to poor multiple pollen tube germination) and 'Avonblue' (due to both lower tetrad viability and lower multiple pollen tube germination).

The pollen grain viability for 'Avonblue' was nearly twice as high as that reported in the nutrient agar germination tests of Goldy and Lyrene (1983), but it was only half that reported in the staining tests of Gupton (1984). Goldy and Lyrene (1983) also germinated 'Sharpblue' pollen, reporting $48 \%$ viability compared to our results of $81 \%$. Consequently, our data indicate that some cultivars ('Avonblue', 'Flordablue') may exhibit the reduced pollen grain viability that Goldy and Lyrene suggested to be associated with poor fertility of interspecific hybrids. However, the high pollen tetrad viabilities and relatively high incidence of multiple tube germinations for 'Georgiagem', 'Gulfcoast', 'O'Neal', and especially 'Sharpblue' suggests that their complex, interspecific ancestries do not adversely affect pollen grain viability.

In vivo studies of southern highbush blueberry pollen fertility, as related to fruit set and development, have been undertaken only recently, with as yet variable results (Gupton, 1984, 1991; Lang and Danka, 1991a, 1991b; Lyrene, 1989). Data from limited cultivar pollination combinations indicate that pollen source has little effect on fruit set, but may have substantial effects on fruit size and ripening date that are suggestive of a xenia/ metaxenia effect. Further understanding of these pollen-based effects and their relationship to cultivar selection will be of vital importance to the development of southern highbush planting recommendations.

\section{Literature Cited}

Brewer, J.W. and R.C. Dobson. 1969. Pollen analysis of two highbush blueberry varieties Vaccinium corymbosum. J. Amer. Soc. Hort. Sci. 94:251-252.

Camp, W.H. 1945. The North American blueberry with notes on other groups of Vacciniaceae. Brittonia 5:203-275.

Cockerham, L.E. and G.J. Galletta. 1976. A survey of pollen characteristics in certain Vaccinium species. J. Amer. Soc. Hort. Sci. 101:671675. 
Eck, P. 1986. Blueberry, p. 75-85. In: S.P. Monselise (ed.). Handbook of fruit set and development. CRC Press, Boca Raton, Fla.

El-Agamy, S.Z.A., W.B. Sherman, and P.M Lyrene. 1981. Fruit set and seed number from self- and cross-pollinated highbush (4x) and rabbiteye (6x) blueberries. J. Amer. Soc. Hort. Sci. 106:443-445.

Galletta, G.J. 1983. Pollen and seed management, p. 23-35. In: J.N. Moore and J. Janick (eds.). Methods in fruit breeding. Purdue Univ. Press, West Lafayette, Ind.

Goldy, R.G. and P.M. Lyrene. 1983. Pollen germination in interspecific Vaccinium hybrids. HortScience 18:54-55.

Gupton, C.L. 1984. Effect of pollen source on fruit characteristics of low-chilling highbush type blueberries. HortScience 19:531-532.

Gupton, C.L. 1991. Interspecific and intraspecific pollination effects in rabbiteye and southern highbush blueberry. HortScience 26:682. (Abstr.)

Knox, R.B. and E. Friederich. 1974. Tetrad pollen grain development and sterility in Leschenaultia formosa. New Phytol. 73:251-258.
Lang, G.A. and R.G. Danka. 1991a. Honey beemediated cross- vs. self-pollination of 'Sharpblue' blueberry affects fruit development period and fruit size. J. Amer. Soc. Hort. Sci. 116:770773.

Lang, G.A. and R.G. Danka. 1991b. The influence of self- and cross-pollination on fruiting in southern highbush blueberries. HortScience 26:486. (Abstr.)

Lang, G.A. and R.G. Danka. 1992. Pollination aspects of fruit production in new southern highbush blueberries. Louisiana Agr. 35:(2)34.

Lyrene, P.M. 1989. Pollen source influences fruiting of 'Sharpblue' blueberry. J. Amer. Soc. Hort. Sci. 114:995-999.

Lyrene, P.M. and W.B. Sherman. 1984. Breeding early-ripening blueberries for Florida. Proc. Fla. State Hort. Soc. 97:322-325.

Parfitt. D.E. and S. Ganeshan. 1989. Comparison of procedures for estimating viability of Prunus pollen. HortScience 24:354-356.

Parrie, E.J. 1990. Pollination of hybrid southern highbush blueberries (Vaccinium corymbosum
L.). MS Thesis, Louisiana State Univ., Baton Rouge.

Sanders, L.C. and E.M. Lord. 1989. Directed movement of latex particles in the gynoecia of three species of flowering plants. Science 243:1606-1608.

Stushnoff, C. and A.J. Feliciano. 1968. A simple technique for observing mitotic division of the generative nucleus in pollen tubes of Vaccinium spp. HortScience 3:174.

Stushnoff, C. and J.A. Hough. 1968. Sporogenesis and gametophyte development in 'Bluecrop' and 'Coville' highbush blueberries. Proc. Amer. Soc. Hort. Sci. 93:242-247.

Stushnoff, C. and B.F. Palser. 1969. Embryology of five Vaccinium taxa including diploid, tetraploid and hexaploid species or cultivars. Phytomorphology 19:312-321.

Vander Kloet, S.P. 1983. The relationship between seed number and pollen viability in Vaccinium corymbosum L. HortScience 18:225-226.

Werner, D.J. and S. Chang. 1981. Stain testing viability in stored peach pollen. HortScience 16:522-523. 